\title{
Subunit-Dependent Modulation of Kainate Receptors by Extracellular Protons and Polyamines
}

\author{
David D. Mott, ${ }^{1}$ Mark S. Washburn, ${ }^{2}$ Sunan Zhang, ${ }^{1}$ and Raymond J. Dingledine ${ }^{1}$ \\ ${ }^{1}$ Department of Pharmacology, Emory University School of Medicine, Atlanta, Georgia 30322, and ${ }^{2}$ Merck Research Laboratories, San Diego, \\ California 92121
}

Synaptic activity causes significant fluctuations in proton concentrations in the brain. Changes in $\mathrm{pH}$ can affect neuronal excitability by acting on ligand-gated channels, including those gated by glutamate. We show here a subunit-dependent regulation of native and recombinant kainate receptors by physiologically relevant proton concentrations. The effect of protons on kainate receptors is voltageindependent and subunit dependent, with GluR5(Q), GluR6(Q), GluR6(R), and GluR6(R)/KA2 receptors being inhibited and GluR6(R)/ KA1 receptors being potentiated.

Mutation of two acidic residues (E396 and E397) to neutral amino acids significantly reduces the proton sensitivity of the GluR6(Q) receptor, suggesting that these residues influence proton inhibition. The endogenous polyamine spermine potentiated GluR6(R) kainate currents in a pH-dependent manner, producing an acidic shift in the $\mathrm{IC}_{50}$ for proton inhibition. Spermine potentiation of GluR6(R) is voltage independent, does not affect receptor desensitization, and only slightly shifts the agonist affinity of the receptor. These results suggest that, similar to its action on NMDA receptors, spermine potentiates kainate receptors by relieving proton inhibition of the receptor. Furthermore, they suggest that fluctuations in brain $\mathrm{pH}$ during both normal and pathological processes could regulate synaptic transmission and plasticity mediated by kainate receptors.

Key words: polyamines; spermine; $\mathrm{pH}$; kainate receptor; NMDA receptor; proton; epilepsy; neurodegeneration; GluR6

\section{Introduction}

Electrical activity in the brain results in significant $\mathrm{pH}$ shifts in neurons, glia, and the interstitial space. The magnitude of $\mathrm{pH}$ fluctuations varies depending on the stimulus delivered, reaching several tenths of a $\mathrm{pH}$ unit during repetitive stimulation (Chessler and Kaila, 1992). During pathophysiological insults, such as spreading depression and ischemia, interstitial $\mathrm{pH}$ can fall to 6.5 and below for prolonged periods (Somjen, 1984; von Hanwehr et al., 1986). Many ligand-gated channels, including those gated by glutamate, are sensitive to extracellular $\mathrm{pH}$. Much attention has focused on the $\mathrm{pH}$ sensitivity of the NMDA class of glutamate receptor (GluR) (Tang et al., 1990; Traynelis and Cull-Candy, 1990). NMDA receptors that lack exon 5 and NR2C are halfmaximally inhibited by protons at approximately $\mathrm{pH}$ 7.3, suggesting that activity-dependent changes in interstitial $\mathrm{pH}$ could regulate their function. In contrast, AMPA receptors are much less proton sensitive, with half-maximal inhibition at pH 6.1 (Lei et al., 2001). Thus, it seems likely that AMPA receptors would be inhibited by protons only during strong pathophysiological insults. Kainate receptors were reported to be only weakly inhibited by protons (Tang et al., 1990; Traynelis and Cull-Candy, 1990). However, these early studies were hampered by the inability of

\footnotetext{
Received Aug. 6, 2002; revised Dec. 3, 2002; accepted Dec. 6, 2002.

This work was supported by the Epilepsy Foundation (D.D.M.), National Alliance for Research on Schizophrenia and Depression (D.D.M.), University Research Council of Emory University (D.D.M.), National Institute of Neurological Disorders and Stroke (R.J.D.), and Bristol Myers Squibb (R.J.D.). We thank N. Ciliax and J. Peters for excellent technical assistance.

Correspondence should be addressed to Dr. David D. Mott, Department of Pharmacology, Rollins Research Center, Room 5010, 1510 Clifton Road, Emory University School of Medicine, Atlanta, GA 30322. E-mail: dmott@pharm.emory.edu.

Copyright $\odot 2003$ Society for Neuroscience $\quad 0270-6474 / 03 / 231179-10 \$ 15.00 / 0$
}

investigators to separate responses mediated by AMPA and kainate receptors. Only recently, with the development of more selective agonists and antagonists, as well as the use of recombinant receptor subunits, has it been possible to study kainate receptors in isolation.

The family of kainate receptors is composed of five different genes that code for the subunits GluR5, GluR6, GluR7, KA1, and KA2 (Chittajallu et al., 1999). These subunits can combine to create a variety of distinct kainate receptors that play different functional roles. For example, in CA3 pyramidal cells of the hippocampus, GluR6-containing kainate receptors participate in synaptic transmission at the mossy fiber-CA3 pyramidal cell synapse but not at commissural synapses (Castillo et al., 1997). In CA1 stratum radiatum interneurons, postsynaptic kainate receptors contain both GluR5 and GluR6 subunits; however, presynaptic kainate receptors that modulate synaptic transmission between these interneurons contain GluR6 but not GluR5 subunits (Mulle et al., 2000). KA1 and KA2 subunits appear to modify the pharmacological and physiological properties of kainate receptors when coexpressed in heteromeric complexes (Herb et al., 1992; Swanson et al., 1998).

Given the highly specialized roles of different kainate receptors, it is important to understand whether receptor activation is modulated by endogenous agents in a subunit-dependent manner. In this study, we identified a prominent subunit-dependent regulation of recombinant kainate receptors by protons and polyamines. Protons inhibit most tested kainate receptors but, surprisingly, potentiate GluR6/KA1 receptors. We focused on the mechanism by which protons inhibit kainate receptors, finding strong similarity between the action of protons on kainate and NMDA receptors. These results suggest that changes in intersti- 
tial $\mathrm{pH}$ may tonically regulate the function of kainate receptors in a subunit-dependent manner. They also add another layer of complexity to our understanding of kainate receptor function in the brain.

\section{Materials and Methods}

Primary hippocampal cell culture. Primary cultures of hippocampal neurons were prepared using a modified version of our method for preparing cortical cultures (Mott et al., 1998). Briefly, the hippocampi were dissected from the brains of embryonic day 19 Sprague Dawley rat pups, dissociated by trituration, and suspended in DMEM supplemented with L-glutamine $(2 \mathrm{~mm})$, penicillin $(100 \mathrm{U} / \mathrm{ml})$-streptomycin $(100 \mu \mathrm{g} / \mathrm{ml})$, and B27 supplement. Cells were plated onto $12 \mathrm{~mm}$ glass coverslips precoated with poly-D-lysine ( $1 \mathrm{mg} / \mathrm{ml}, 12 \mathrm{hr}$ exposure $)$ and laminin (50 $\mu \mathrm{g} / \mathrm{ml}, 1 \mathrm{hr}$ exposure) and maintained at $37^{\circ} \mathrm{C}$ in a humidified $5 \% \mathrm{CO}_{2}$ incubator.

Electrophysiological recording from primary hippocampal neurons. After $7-15 \mathrm{~d}$ in culture, a coverslip containing neurons was placed in the recording chamber and continually perfused with warmed $\left(30-32^{\circ} \mathrm{C}\right)$, bubbled $\left(95 \% \mathrm{O}_{2}-5 \% \mathrm{CO}_{2}\right)$ artificial CSF (ACSF) at a rate of $2 \mathrm{ml} / \mathrm{min}$. The ACSF contained the following (in $\mathrm{mm}$ ): $125 \mathrm{NaCl}, 2.8 \mathrm{KCl}, 25$ $\mathrm{NaHCO}_{3}, 1.00 \mathrm{NaH}_{2} \mathrm{PO}_{4}, 2 \mathrm{CaCl}_{2}, 1.5 \mathrm{MgSO}_{4}$, and 25 glucose at pH 7.3. Cells were observed with an upright Olympus Optical (Melville, NY) BX50WI microscope equipped with a $40 \times$ water immersion differential interference contrast objective coupled to an infrared camera system (Hamamatsu, Tokyo, Japan). Neurons selected for recording were large and had a pyramidal appearance with two to three dendritic processes.

Recordings were made using conventional whole-cell voltage-clamp techniques (Mott et al., 2001) with a MultiClamp 700A amplifier (Axon Instruments, Union City, CA). Pipettes (resistance $\sim 5 \mathrm{M} \Omega$ ) were filled with the following solution (in $\mathrm{mM}$ ): $110 \mathrm{CsGluconate,} 20 \mathrm{CsCl}, 4 \mathrm{NaCl}$, 10 HEPES, $0.5 \mathrm{CaCl}_{2}, 5$ BAPTA, 2 MgATP, and $0.3 \mathrm{NaGTP}, \mathrm{pH} 7.3$ (285-295 mOsm). Cells were held in voltage clamp at $-70 \mathrm{mV}$ throughout the experiment. Data were filtered at $1 \mathrm{kHz}$ and digitized at $2 \mathrm{kHz}$ using a Digidata 1200 (Axon Instruments) analog-to-digital board. During the experiment, the flow rate of ACSF was increased by means of a peristaltic pump (Minipuls 3; Gilson, Middleton, WI) to $10 \mathrm{ml} / \mathrm{min}$ to decrease solution exchange time. Kainate receptor-mediated currents were isolated by application of a drug mixture containing antagonists of AMPA receptors (GYKI 52466, $100 \mu \mathrm{M}$ ), NMDA receptors (D-APV, 100 $\mu \mathrm{M}$ ), and $\mathrm{GABA}_{\mathrm{A}}$ receptors (bicuculline methochloride, $100 \mu \mathrm{M}$ ). In the presence of this drug mixture, kainate receptor-mediated currents were evoked by bath application of domoate $(100 \mu \mathrm{M})$ for $90 \mathrm{sec}$. Agonist was bath applied in these experiments to allow tight control over the $\mathrm{pH}$ of the solution. $\mathrm{pH}$ levels in the recording chamber were monitored by means of a miniature $\mathrm{pH}$ probe (LAZAR Research Laboratories, Los Angeles, CA) and did not drift by $>0.05 \mathrm{pH}$ units from the desired $\mathrm{pH}$ over the course of the experiment. Domoate was chosen as the agonist because it is weakly desensitizing and could be used in supramaximal concentrations $(100 \mu \mathrm{M})$ to speed the onset of the current. To test the effect of protons on native kainate receptors, ACSF at $\mathrm{pH} 6.3$ was used. This ACSF contained the following (in $\mathrm{mM}$ ): $147.5 \mathrm{NaCl}, 2.8 \mathrm{KCl}, 2.5$ $\mathrm{NaHCO}_{3}, 1.00 \mathrm{NaH}_{2} \mathrm{PO}_{4}, 2 \mathrm{CaCl}_{2}, 1.5 \mathrm{MgSO}_{4}$, and 25 glucose. Neurons were allowed to equilibrate to the desired $\mathrm{pH}$ level for $30-60 \mathrm{sec}$ or until a stable baseline had been reached before domoate application. Series resistance, input resistance, and baseline holding current were monitored throughout the experiment. Neurons in which any of these parameters varied by $>10 \%$ were discarded.

Oocyte preparation and injection. Xenopus oocytes were prepared and injected as described previously (Mott et al., 1998). Briefly, stage V-VI oocytes were isolated from anesthetized frogs, enzymatically treated by gentle shaking with collagenase (type IV, $1.7 \mathrm{mg} / \mathrm{ml}$ for $45-120 \mathrm{~min}$; Worthington, Freehold, NJ) in a calcium-free Barth's solution and then (in some cases) manually defolliculated. Cells were injected with up to 50 ng of mRNA transcribed from linearized constructs in the pGEM-HE, pSGEM, or Bluescript (Stratagene, La Jolla, CA) vector. For heteromeric receptors, mRNA was injected at a 10:1 ratio (GluR2/GluR3), a 1:6 ratio (GluR6/KA1 and GluR6/KA2), or a 1:3 ratio (NR1/NR2). Injected oo- cytes were maintained at $17^{\circ} \mathrm{C}$ in Barth's solution containing gentamycin $(100 \mu \mathrm{g} / \mathrm{ml})$, penicillin $(10 \mathrm{U} / \mathrm{ml})$, and streptomycin $(10 \mu \mathrm{g} / \mathrm{ml})$ for 3-10 $\mathrm{d}$, after which two-electrode voltage-clamp recordings were made at room temperature $\left(23-25^{\circ} \mathrm{C}\right)$ from cells continually perfused in a standard frog Ringer's solution. This solution contained the following (in $\mathrm{mm}$ ): $90 \mathrm{NaCl}, 1 \mathrm{KCl}, 15 \mathrm{HEPES}$, and $0.4 \mathrm{CaCl}_{2}$ and $0.1 \mathrm{MgCl}_{2}$. Recording pipettes were filled with $3 \mathrm{M} \mathrm{CsCl}$ plus $0.4 \mathrm{~m}$ EGTA, pH 7.5, to chelate $\mathrm{Ca}^{2+}$ and thereby minimize the activation of calcium-dependent chloride currents. GluR6/KA1 and GluR6/KA2 receptors were activated with AMPA (0.3-1 mM), whereas homomeric receptors were activated by domoate $(3 \mu \mathrm{M})$ or kainate $(30 \mu \mathrm{M})$. To reduce desensitization when kainate was used as the agonist, oocytes were pretreated with concanavalin-A $(0.3 \mathrm{mg} / \mathrm{ml}$ for $3 \mathrm{~min})$ and then washed for at least $10 \mathrm{~min}$ before use. NMDA receptors were activated using NMDA (100 $\mu \mathrm{M})$ and glycine (10 $\mu \mathrm{M})$, and AMPA receptors were activated with kainate $(300 \mu \mathrm{M})$. When NMDA receptors were studied, the $\mathrm{MgCl}_{2}$ in the Ringer's solution was replaced with $0.4 \mathrm{~mm} \mathrm{BaCl}_{2}$. Currents were elicited from a holding potential of $-70 \mathrm{mV}$ except when specified. Current signals were digitized at $1 \mathrm{kHz}$ using a Digidata 1200 analog-to-digital board (Axon Instruments). Current-voltage $(I-V)$ curves during steady-state current responses were generated using voltage ramps from -100 to $+50 \mathrm{mV}$ over a period of $1.3 \mathrm{sec}$. Ramp currents were analyzed by subtracting the average of the leak current before and after agonist application from the current obtained in the presence of agonist. At least three ramps were recorded and averaged for each condition in each oocyte. To study the effect of $\mathrm{pH}$, oocytes were perfused with Ringer's solution at the desired $\mathrm{pH}$ for 30-60 sec or until a stable baseline had been reached before subsequent agonist application. Application of each of the agonists produced a stable, rapidly rising and nondesensitizing or weakly desensitizing current in the majority of oocytes. Oocytes in which the current was not stable or in which the baseline holding current drifted by $>10 \%$ were discarded.

Human embryonic kidney 293 cell culture and transfection. Human embryonic kidney 293 (HEK 293) cells (CRL 1573; American Type Culture Collection, Manassas, VA) were cultured in DMEM containing high glucose $(25 \mathrm{~mm})$ and added L-glutamine (2 mM), sodium pyruvate (1 mM), penicillin $(100 \mathrm{U} / \mathrm{ml})$-streptomycin $(100 \mu \mathrm{g} / \mathrm{ml})$, and $10 \%$ fetal bovine serum according to Mott et al. (2001). Cells were maintained in $60 \mathrm{~mm}$ culture plates at $37^{\circ} \mathrm{C}$ in a humidified atmosphere containing $5 \% \mathrm{CO}_{2}$, grown to $\sim 80 \%$ confluency (usually $\sim 48 \mathrm{hr}$ after plating), harvested enzymatically using $0.25 \%$ trypsin, and dissociated further by gentle trituration. For maintenance, cells were then replated in $60 \mathrm{~mm}$ culture dishes at a ratio of 1:5 with growth media. For transfection, cells were plated at a density of $10^{6}$ cells $/ \mathrm{ml}$ on $12 \mathrm{~mm}$ glass coverslips coated first with poly-Dlysine (2-12 hr exposure; $100 \mathrm{mg} / \mathrm{ml})$ and then with fibronectin $(2-12 \mathrm{hr}$ exposure; $20 \mathrm{mg} / \mathrm{ml}$ ). After $24-48 \mathrm{hr}$, cells were transfected by the method of calcium phosphate precipitation as described previously (Mott et al., 2001) with $0.1-1 \mathrm{mg} / \mathrm{ml}$ GluR6(Q) in the cytomegalovirus-based mammalian expression vector JG3.6 or GluR6(R) in pcDNAlamp. Cotransfection with the reporter gene green fluorescent protein $(0.2-0.4 \mathrm{mg} / \mathrm{ml})$ was used to identify individually transfected cells.

Electrophysiological recording from HEK 293 cells. Transfected HEK 293 cells plated on a glass coverslips were transferred to a perfusion chamber on the stage of an inverted microscope (Diaphot; Nikon, Tokyo, Japan) and continually perfused at a rate of $0.5 \mathrm{ml} / \mathrm{min}$ with $23^{\circ} \mathrm{C}$ media containing the following (in $\mathrm{mM}$ ): $150 \mathrm{NaCl}, 3 \mathrm{KCl}, 10 \mathrm{HEPES}, 1 \mathrm{CaCl}_{2}$, and $0.4 \mathrm{MgCl}_{2}$. Whole-cell recordings of agonist-evoked membrane currents were performed under voltage-clamp conditions (Mott et al., 2001) with electrodes containing the following (in $\mathrm{mM}$ ): $110 \mathrm{D}$-gluconic acid, 110 $\mathrm{CsOH}, 30 \mathrm{CsCl}, 4 \mathrm{NaCl}, 5 \mathrm{HEPES}, 5$ BAPTA, $0.5 \mathrm{CaCl}_{2}, 2 \mathrm{MgCl}_{2}, 2$ $\mathrm{NaATP}$, and 0.3 NaGTP at pH 7.3 (osmolality was $290 \mathrm{mOsm}$ ). Recording electrodes were made from borosilicate glass (inner diameter, 1.15; outer diameter, 1.65) fire polished to resistance of 4-6 M $\Omega$. The membrane potential was held between -60 and $-75 \mathrm{mV}$ unless otherwise specified. Current recordings were amplified (Axopatch 200; Axon Instruments), filtered ( $1-3 \mathrm{kHz},-3 \mathrm{~dB})$, and digitized at $3-13 \mathrm{kHz}$ using a Digidata 1200 analog-to-digital board. Tip potentials were measured after each patch experiment, and experiments with slow or multiphasic exchange time courses were excluded. For whole-cell recordings, cells were lifted off of the bottom of the dish to facilitate solution exchange. 
Slow solution changes were performed by exchanging the total volume of the recording chamber. Rapid solution changes were performed with a piezoelectric-driven double-barreled perfusion system (model P-272.00; Physik Instrumente, Waldbronn, Germany) (Mott et al., 2001). The application pipette was pulled from theta glass tubing $(2 \mathrm{~mm}$ outer diameter, $0.3 \mathrm{~mm}$ wall thickness, $0.22 \mathrm{~mm}$ septum; Hilgenberg, Malsfeld, Germany) and had a tip diameter of 200-300 $\mu \mathrm{m}$, with the inner diameter of each barrel being $80-120 \mu \mathrm{m}$. A solenoid valve typically controlled flow in each side of the theta tubing. Control solution flowed continuously through one barrel, whereas the agonist solution flowed through the other barrel only during drug application. The agonist application barrel was preflushed for $1-2$ sec before piezo-driven application to clear diluted solution and moved by means of a piezoelectric device causing the recorded cell or membrane patch to be transiently exposed to the agonist-containing solution. The time course of solution exchange across the laminar flow interface was estimated at the end of each experiment by liquid junction potential measurements and was found to possess a $20-80 \%$ rise time of $300-500 \mu \mathrm{sec}$. The solution flowing through the application pipette could be changed by means of a rotary valve connected to each barrel. Between solution changes, the agonist application barrel was flushed for 20-60 sec to remove the previous solution. Unless otherwise stated, agonist was applied at intervals at which the receptors were shown to completely recover $(4 \times$ mean tau; 99\%) from desensitization (15 sec for glutamate and $45 \mathrm{sec}$ for kainate). All experiments were performed using 1-3 mM glutamate or $300 \mu \mathrm{M}$ kainate, unless otherwise indicated.

Data analysis. Analysis was performed using pClamp (Axon Instruments), Origin (Microcal Software, Northampton, MA), and Prism software (GraphPad Software, San Diego, CA) packages. Statistical comparisons were performed using the appropriate Student's $t$ test. A two-way ANOVA with Bonferroni post hoc test to compare selected means was performed for the analysis of the data presented in Figure $4 D$. Values are given as mean $\pm \mathrm{SE}$.

Materials. GluR6(Q) and GluR6(R) in pGEM-HE and the pSGEM vector were a generous gift from M. Mayer (National Institutes of Health, Bethesda, MD). GluR6(Q) in JG3.6 was generously provided by S. Heinemann (Salk Institute, San Diego, CA), as were GluR5, KA1 and KA2 plasmids. NR1 and NR2 were generously provided by S. Nakanishi (Kyoto University, Kyoto, Japan). Philanthotoxin-433 (PhTx-433) was a generous gift from A. Mueller (NPS Pharmaceuticals, Salt Lake City, UT). Kainate, spermine, spermidine, GYKI 52466, and glycine were purchased from Sigma (St. Louis, MO). Domoate, AMPA, D-APV, bicuculline methochloride, and NMDA were purchased from Tocris Cookson (St. Louis, MO). All tissue culture reagents were obtained from Invitrogen (Gaithersburg, MD). Molecular biology reagents, restriction enzymes, and fibronectin were purchased from Promega (Madison, WI), Pharmacia (Piscataway, NJ), or Boehringer Mannheim (Indianapolis, IN).

\section{Results}

\section{Inhibition of native and recombinant kainate receptors} by protons

Kainate receptors expressed in cultured hippocampal neurons can be activated in a weakly desensitizing manner by domoate (Lerma et al., 1993). We made use of this finding to test the proton sensitivity of native kainate receptors in cultured hippocampal neurons. Activation of pharmacologically isolated kainate receptors with domoate $(100 \mu \mathrm{M})$ at $\mathrm{pH} 7.3$ and a holding potential of $-70 \mathrm{mV}$ produced inward currents. Decreasing the $\mathrm{pH}$ to 6.3 significantly reduced the amplitude of this current (Fig. $1 A$ ). Returning the $\mathrm{pH}$ to 7.3 rapidly restored the current amplitude. These data indicate that protons inhibit native kainate receptors in cultured hippocampal neurons.

To explore this finding in greater detail, we examined the effect of protons on recombinant kainate receptors. Steady-state domoate-evoked $(3 \mu \mathrm{M})$ currents in oocytes injected with the unedited $(\mathrm{Q})$ variant of GluR6 were decreased when the $\mathrm{pH}$ was

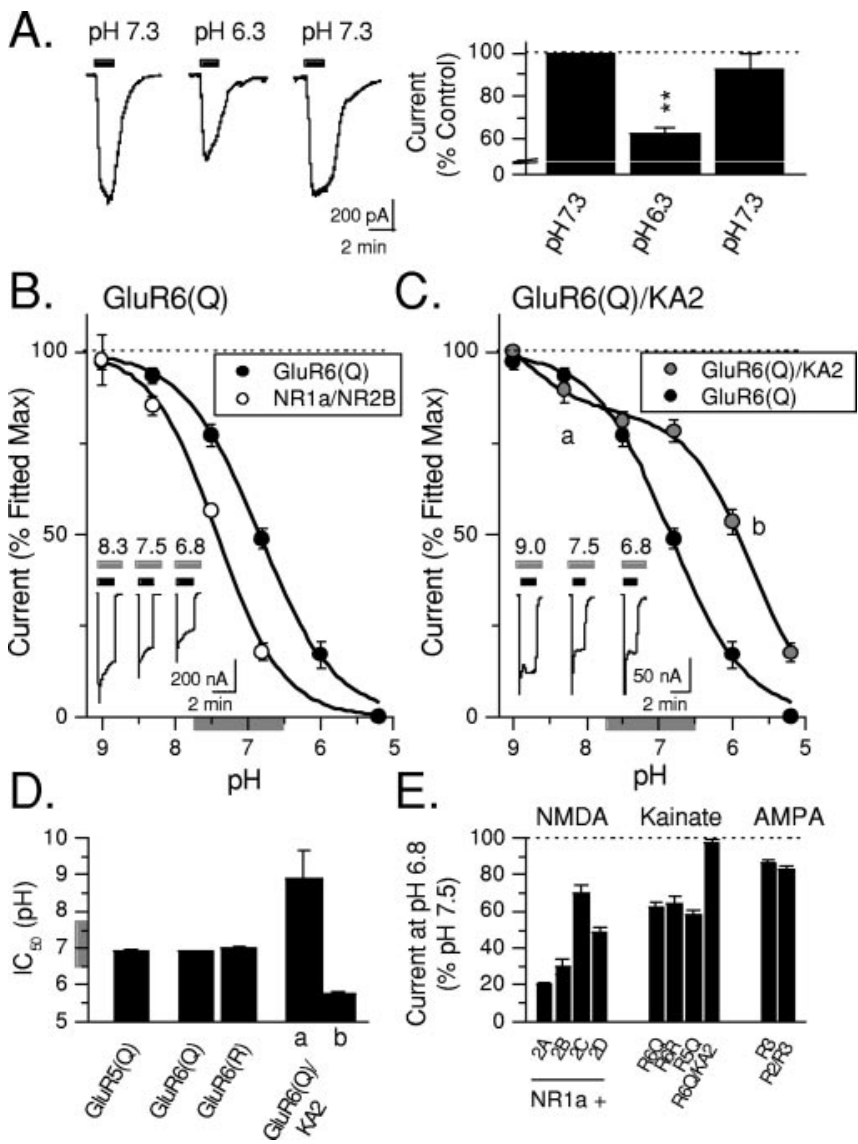

Figure 1. Protons inhibit native and recombinant kainate receptors in a subunit-dependent manner. $A$, Pharmacologically isolated kainate currents from a cultured hippocampal neuron during application of domoate $(100 \mu \mathrm{m})$ at pH 7.3, pH 6.3, and after wash at pH 7.3. The bar graph on the right compares the averaged effect of acidic $\mathrm{pH}$ on kainate receptor-mediated currents in cultured hippocampal neurons $\left(n=4 ;{ }^{* *} p<0.01\right)$. Responses were normalized relative to the initial control current at $\mathrm{pH} 7.3$ (dotted line). $B$, Dose-response curves to protons for GluR6( $Q$ ) ( filled circles; $n=7$ ) and NR1a/NR2B NMDA receptors (open circles; $n=5-8$ 00 cytes per $\mathrm{pH}$ level) expressed in 0ocytes. The $\mathrm{pH}$ levels at which proton inhibition of GluR6(Q) $\left(\mathrm{IC}_{50}\right.$ of pH $\left.6.9 \pm 0.03\right)$ and NR1a/NR2B receptors $\left(\mathrm{IC}_{50}\right.$ of $\left.\mathrm{pH} 7.42 \pm 0.06\right)$ were half-maximal were both within a biologically relevant range of proton concentrations ( gray bar in this and subsequent figures). The dotted line indicates the extrapolated maximum current used for normalization (see Results). The inset shows sample recordings of domoate currents from GluR6(Q) receptors at different $\mathrm{pH}$ levels. The gray bars denote application of the indicated $\mathrm{pH}$, whereas the black bars indicate domoate ( $3 \mu \mathrm{m}$ ) application. C, Dose-response curve to protons for GluR6(Q)/KA2 receptors expressed in oocytes. Protons inhibited this receptor in a biphasic manner with $\mathrm{IC}_{50}$ values at $\mathrm{pH} 8.9 \pm 0.8(a)$ and $5.8 \pm 0.1(b ; n=11)$. The proton inhibition curve for GluR6(Q) is plotted for comparison. The dotted line indicates the extrapolated maximum current used for normalization (see Results). The inset shows sample currents from GluR6(Q)/ KA2 receptors activated by AMPA at different $\mathrm{pH}$ levels. The gray bars denote application of the indicated $\mathrm{pH}$, whereas the black bars indicate (s)-AMPA (300 $\mu \mathrm{M})$ application. D, The bar graph compares the $\mathrm{pH}$ level necessary to produce half-maximal inhibition $\left(\mathrm{IC}_{50}\right)$ of each of the indicated kainate receptors expressed in oocytes. Because the proton inhibition curve for $\mathrm{GluR6}(\mathrm{Q})$ / $\mathrm{KA} 2$ is biphasic $(C)$, both $\mathrm{IC}{ }_{50}$ values are indicated. The number of 00 cytes used for each receptor is as follows (oocytes per point on the proton inhibition curve): GluR5(Q), 8; GluR6(Q), 6-20; GluR6(R), 4-20; GluR6(Q)/KA2, 5-7. E, Comparison of the effect of protons on selected NMDA, kainate, and AMPA receptors expressed in 0ocytes. Current amplitudes at $\mathrm{pH} 6.8$ are expressed as a percentage of the amplitude at $\mathrm{pH} 7.5$ (dotted line). The number of oocytes used is as follows: NR1a/NR2A, 7; NR1a/NR2B, 6;NR1a/NR2C, 6;NR1a/NR2D, 5;GluR6(0), 15;GluR6(R), 7; GluR5(Q), 8; GluR6(Q)/KA2, 10; GluR3, 11; GluR2/GluR3, 4.

lowered and were potentiated when the $\mathrm{pH}$ was raised above $\mathrm{pH}$ 7.5. Proton inhibition of these currents was rapidly reversible during washout. A composite inhibition curve describing the effect of protons on GluR6(Q) receptors was produced by record- 
ing the domoate current from each oocyte over a $\mathrm{pH}$ range from 9.0 to 5.2 and then expressing this current as a percentage of the current at $\mathrm{pH}$ 7.5. The results from each oocyte were then normalized to the extrapolated maximum response in that oocyte, combined, and plotted in Figure $1 B$. The $\mathrm{IC}_{50}$ determined from the fitted curve for GluR6(Q) was approximately pH $6.9(\sim 126$ $\mathrm{nM} \mathrm{H}^{+}$), whereas that for NR1a/NR2B receptors was approximately $\mathrm{pH}$ 7.4. These data indicate that, as with NMDA receptors, GluR6 receptors are tonically inhibited by protons at $\mathrm{pH}$ 7.3.

It is unlikely that ionization of domoate contributed to the $\mathrm{pH}$-dependent effects of this agonist. The three carboxylic acids of domoic acid have $\mathrm{p}_{\mathrm{Ka}}$ values of 2.1,3.7, and 5.0, with the amino group in the pentameric ring having a $\mathrm{p}_{\mathrm{Ka}}$ of 9.8 . These values are all outside of the $\mathrm{pH}$ range tested in these experiments. Furthermore, a supramaximal concentration of domoate was used in all experiments to minimize any potential effects of changes in the ionization of this agonist.

\section{Subunit dependence of proton inhibition}

Kainate receptors of distinct subunit composition play different functional roles. Differential proton sensitivity of these receptors may provide a novel method of regulating kainate receptormediated neurotransmission. Therefore, we examined the proton sensitivity of kainate receptors of different subunit composition. GluR5(Q) kainate receptors were inhibited by protons with an $\mathrm{IC}_{50}$ of $\mathrm{pH} 6.9 \pm 0.04$. This value was similar to that of GluR6(Q), suggesting that GluR5 kainate receptors would also be tonically inhibited by ambient proton concentrations. GluR5 and GluR6 subunits are subject to RNA editing, which converts a single amino acid residue in the channel pore from a glutamine (Q) into an arginine (R) (Sommer et al., 1991). Editing at this $\mathrm{Q} / \mathrm{R}$ site in GluR6 did not affect proton inhibition [GluR6(R) $\mathrm{IC}_{50}$ of $7.0 \pm 0.04$ ] (Fig. $\left.1 \mathrm{D}\right)$.

We examined the proton sensitivity of a heteromeric kainate receptor by expressing the GluR6(Q) subunit in combination with KA2 subunits. GluR6(Q)/KA2 receptors were selectively activated by bath application of (s)-AMPA (300 $\mu \mathrm{M})$ (Herb et al., 1992). Protons inhibited current at these receptors, but the proton inhibition curve was biphasic, with $\mathrm{IC}_{50}$ values at approximately $\mathrm{pH} 8.9$ and 5.8 , respectively (Fig. $1 C, D$ ). When compared with GluR6(Q) receptors, GluR6(Q)/KA2 receptors were equally sensitive to low proton concentrations $(\mathrm{pH} \geq 7.5)$ and less sensitive to higher proton concentrations ( $\mathrm{pH}<7.5)$. Interestingly, although the current at GluR6(Q)/KA2 receptors was inhibited by $\sim 25 \%$ between $\mathrm{pH} 7.5$ and 6.8 , the extent of proton inhibition did not significantly change as the $\mathrm{pH}$ was altered over this range. It is unlikely that ionization of AMPA contributes to the $\mathrm{pH}$ dependent effects of this agonist because the $\mathrm{p}_{\mathrm{Ka}}$ values for AMPA $\left(\mathrm{p}_{\mathrm{Ka} 1}=1.9 ; \mathrm{p}_{\mathrm{Ka} 2}=5.1 ;\right.$ and $\left.\mathrm{p}_{\mathrm{Ka} 3}=10.1\right)$ fall outside of the tested $\mathrm{pH}$ values.

The current amplitude at $\mathrm{pH} 6.8$ as a percentage of the current at $\mathrm{pH} 7.5$ gives a measure of proton inhibition over a biologically relevant portion of the $\mathrm{pH}$ range. This type of comparison between kainate, NMDA, and AMPA receptors of selected subunit composition reveals that homomeric kainate receptors (GluR5 and GluR6) have intermediate proton sensitivity between that of NMDA and AMPA receptors, with NR1a/NR2C NMDA receptors being less proton sensitive than all tested kainate receptors except GluR6(Q)/KA2 (Fig. 1E).

\section{Protons potentiate current at GluR6(Q)/KA1 receptors}

In contrast to the strong inhibition produced by protons on homomeric or heteromeric GluR6(Q)/KA2-containing kainate re-
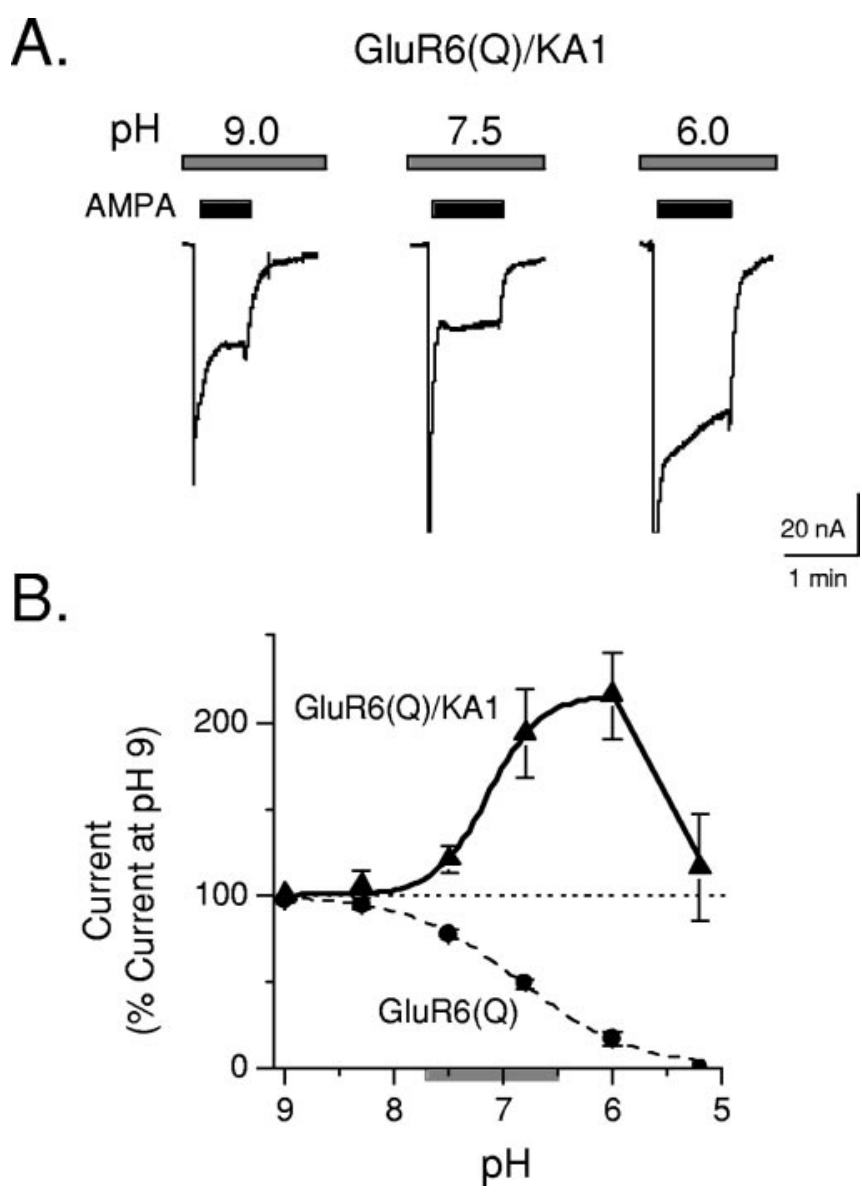

Figure 2. Protons potentiate kainate current at GluR6/KA1 receptors. $A$, GluR6(Q)/KA1 currents activated by (s)-AMPA $(300 \mu \mathrm{M})$ in oocytes at different pH levels. Note the increased current amplitude at $\mathrm{pH} 6.0$. Also in this oocyte note the atypical increase in current at $\mathrm{pH} 9.0 . \mathrm{B}$, Dose-response curve to protons at GluR6(Q)/KA1 receptors expressed in oocytes $(n=8)$. The dotted line indicates the current amplitude at $\mathrm{pH} 9.0$ used for normalization. The proton inhibition curve for GluR6(Q) is indicated for comparison (dashed line).

ceptors, protons potentiated kainate receptors containing GluR6(Q)/KA1 subunits. Proton potentiation of current at these receptors became stronger as proton concentrations were increased from $1 \mathrm{nM}(\mathrm{pH}$ 9.0) up to $1 \mu \mathrm{M}(\mathrm{pH} \mathrm{6.0)}$. At proton concentrations above $1 \mu \mathrm{M}(\mathrm{pH}<6.0)$, potentiation of the kainate current was reversed (Fig. $2 A, B$ ). Proton potentiation was rapidly reversible during washout. Protons potentiated GluR6(Q)/KA1 receptors with an $\mathrm{EC}_{50}$ of $\mathrm{pH} 7.1 \pm 0.03$, indicating that these receptors were more sensitive to protons than other tested kainate receptors. In two of the eight oocytes tested, the current was also slightly potentiated at very alkaline $\mathrm{pH}$ values (Fig. $2 \mathrm{~A}$ ), suggesting that protons may act at more than one site on these receptors.

Whereas the mechanism of proton inhibition of kainate receptors is unknown, proton inhibition of NMDA receptors has been well characterized. Protons inhibit NMDA receptors by binding to an allosteric site on the extracellular face of the receptor and decreasing the single-channel opening frequency (Traynelis and Cull-Candy, 1990). Protons do not alter the rate or extent of NMDA receptor desensitization nor do they alter agonist affinity at the receptor (Tang et al., 1990; Traynelis and Cull-Candy, 1990, 1991). Proton inhibition of NMDA receptors is voltage independent and does not involve a shift in the reversal potential of the current. Finally, polyamines potentiate current at 
A.

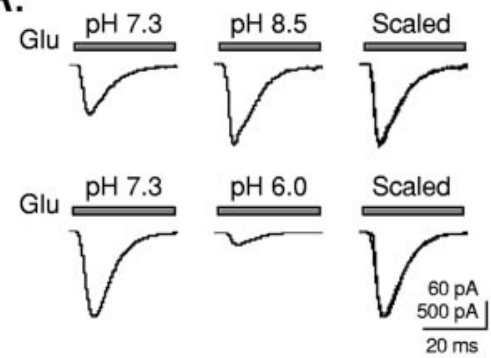

B.
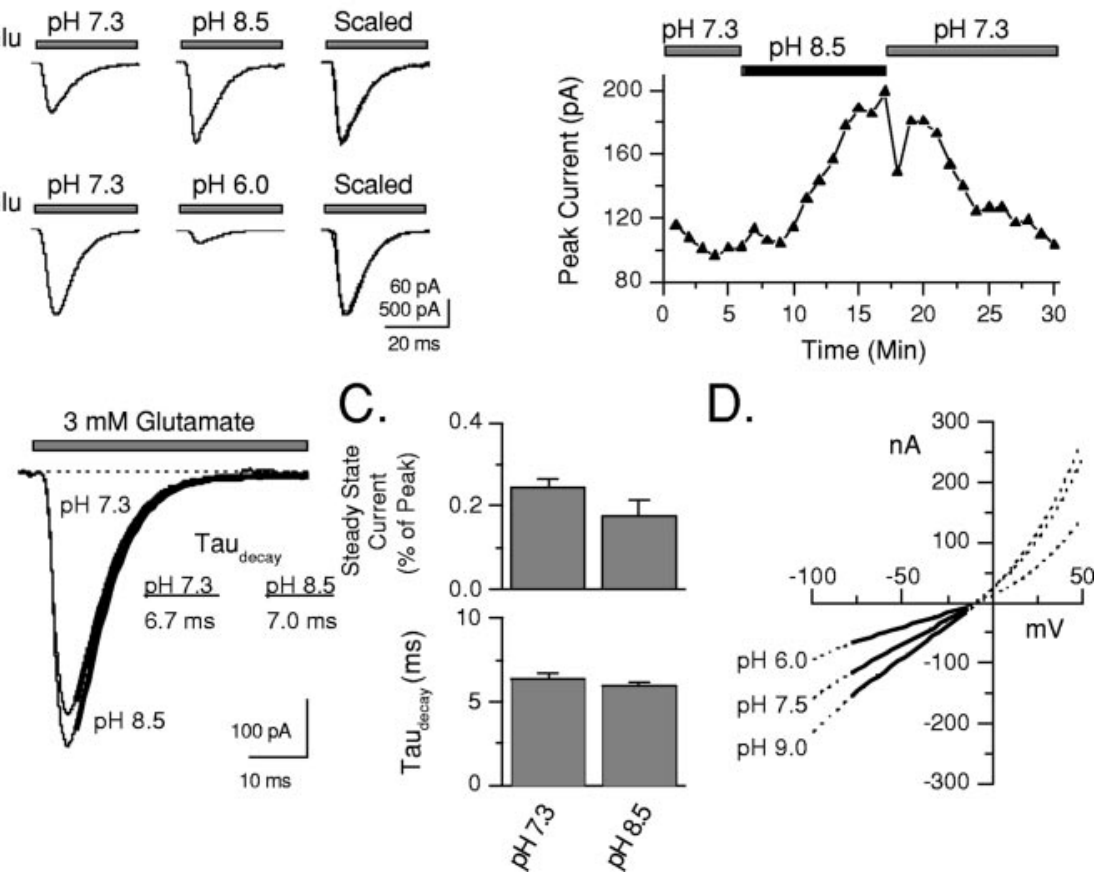

D.

Figure 3. Protons do not alter desensitization kinetics or voltage dependence of GluR6 kainate receptors. $A, \operatorname{The} G$ luR6(Q) current produced by rapid application of glutamate ( $3 \mathrm{~mm}$ ) to HEK 293 cells held at $-70 \mathrm{mV}$ was potentiated by $60 \%$ at alkaline $\mathrm{pH}(\mathrm{pH} 8.5$ ) in one cell and inhibited by $85 \%$ at acidic $\mathrm{pH}$ ( $\mathrm{pH} 6.0$ ) in another cell. The lack of change in response kinetics at altered $\mathrm{pH}$ can be seen when the currents are scaled and superimposed. The graph on the right shows the amplitude of the GluR6(Q) current in response to rapid application of glutamate during the course of one experiment as the $\mathrm{pH}$ was increased to 8.5 and then returned to 7.3. On average, $\mathrm{pH} 8.5$ caused a $15 \pm 5 \%(p<0.05 ; n=5)$ increase in GluR6(Q) current amplitude. $B$, Superimposition of GluR6( $Q$ ) currents in response to rapid application of glutamate at $\mathrm{pH} 7.3$ and 8.5. Monoexponential fits of the current decay demonstrate that, despite the increased current amplitude, the desensitization kinetics of the current did not change. $C_{\text {, }}$ Top, Desensitization of GluR6(Q) currents was almost complete. Steady-state current amplitudes were determined from monoexponential fits of current decay and averaged only $\sim 0.24 \%$ of peak amplitude $(n=4)$. Alkaline pH (pH 8.5$)$ produced a small but nonsignificant decrease in steady-state/peak current ratio. Bottom, The time constant of current decay $\left(\tau_{\text {decay }}\right)$ did not change as the $\mathrm{pH}$ was increased from pH 7.3 to $8.5(n=4)$. D, In 0ocytes, the domoate $(3 \mathrm{~mm})$ current at GluR6(R) receptors at three different $\mathrm{pH}$ levels was outwardly rectifying during voltage ramps from -100 to $+50 \mathrm{mV}$ as evident in these sample traces (dotted lines). The slope of the linear portion of the $I-V$ curve, calculated by regression analysis, is shown (thick lines).

NR1a/NR2B NMDA receptors primarily by relieving proton inhibition (Traynelis et al., 1995). Using NMDA receptors as a model, we examined the mechanism of proton inhibition of kainate receptors. We focused our attention on GluR6 kainate receptors.

\section{Protons do not alter GluR6 receptor desensitization kinetics} Protons do not alter desensitization of NMDA receptors (Traynelis and Cull-Candy, 1991). In contrast, protons inhibit AMPA receptors by enhancing receptor desensitization (Ihle and Patneau, 2000; Lei et al., 2001). We examined the effect of protons on the desensitization kinetics of GluR6(Q) kainate receptors expressed in HEK 293 cells to determine whether the mechanism of proton inhibition of kainate receptors was similar to that of NMDA or AMPA receptors. Rapid application of a supramaximal concentration of glutamate $(3 \mathrm{~mm}, \mathrm{pH} 7.3)$ produced a strongly desensitizing response in whole-cell recordings of GluR6(Q) currents in these cells. The rapid monophasic rise of the current $\left(\tau_{\text {rise }}=720 \pm 80 \mu \mathrm{sec}\right)$ and the sharp current peak suggest that GluR6 receptors are activated synchronously. At $\mathrm{pH}$ 7.3, desensitization of the current was well fitted by a single exponential component, with $\tau_{\text {desens }}=6.4 \pm 0.3 \mathrm{msec}$ and a peak/ steady-state current ratio of $410 \pm 30(n=8)$. Alkaline $\mathrm{pH}(\mathrm{pH}$ 8.5) increased, whereas acidic $\mathrm{pH}(\mathrm{pH}$ 6.0) decreased peak cur- rent amplitude. However, neither alkaline nor acidic $\mathrm{pH}$ altered GluR6(Q) current kinetics, as can be seen when the current traces are scaled and superimposed (Fig. $3 A)$. Closer examination of desensitization kinetics of GluR6(Q) revealed that alkaline $\mathrm{pH}$ did not significantly alter $\tau_{\text {desens }}$ or the peak/steady-state current ratio (Fig. $3 B, C)$. These data suggest that, similar to NMDA receptors, proton inhibition of GluR6 kainate receptors is not caused by changes in the extent or rate of onset of desensitization.

\section{Proton inhibition of kainate receptors is voltage insensitive}

The voltage sensitivity of proton inhibition of kainate receptors was examined to determine whether protons inhibit these receptors by acting at a site within the transmembrane electric field. Domoate currents at $\mathrm{pH}$ 6.0, 7.5, and 9.0 were recorded from GluR6(R)-injected oocytes as the holding potential was ramped from -100 to $+50 \mathrm{mV}$. Domoate currents reversed close to $0 \mathrm{mV}$ at all $\mathrm{pH}$ levels tested ( $\mathrm{pH} 9, I_{\mathrm{REV}}-2 \pm 8 \mathrm{mV}$; pH 7.5, $I_{\mathrm{REV}}-2 \pm$ $8 \mathrm{mV}$; pH 6.0, $\left.I_{\mathrm{REV}}-1 \pm 8 \mathrm{mV} ; n=4\right)$ and were approximately linearly dependent on voltage over the range from -80 to -20 $\mathrm{mV}$. The slope of this region of the current-voltage curve was dependent on $\mathrm{pH}$ in a manner quantitatively similar to that of steady-state currents in these same oocytes. The average slope increased by $70 \pm$ $40 \%$ when the $\mathrm{pH}$ was raised to $\mathrm{pH} 9.0$ and decreased by $40 \pm 18 \%$ when the $\mathrm{pH}$ was lowered to $\mathrm{pH} 6.0$ (Fig. 3D), whereas the steady-state current at $-70 \mathrm{mV}$ increased by $60 \pm 17 \%$ at $\mathrm{pH} 9.0$ and decreased by $50 \pm 4 \%$ at $\mathrm{pH} 6.0(n=$ 4). Finally, the lack of an increase in outward rectification of the current at $\mathrm{pH} 6.0$ [rectification ratio-100/50 ( $\left.\mathrm{RR}_{-100 / 50}\right), 1.2 \pm$ $0.1, \mathrm{pH} 7.5 ; 1.3 \pm 0.1, \mathrm{pH} 6.0 ; n=4]$ suggested that proton inhibition of GluR6(R) kainate receptors is voltage insensitive.

\section{Mutations in GluR6(Q) reduce proton inhibition}

Site-directed mutagenesis has identified a number of acidic amino acid residues on the NR1 NMDA receptor subunit that are critical for proton inhibition of that receptor (Williams et al., 1995; Masuko et al., 1999). Two residues of particular interest are glutamate 342 and aspartate 343 . These neighboring residues are located in the N terminus of the NR1 subunit in the region connecting the two lobes of the LIVBP-like domain. Sequence alignment of NR1a, NR2A-NR2D with GluR5-GluR7 reveals that, in seven of eight subunits, E342 is conserved, whereas the neighboring residue at position 343 is acidic (either aspartate or glutamate, differing only in NR2C) (alignments adapted from those of Armstrong et al., 1998; Paoletti et al., 2000; Perin-Dureau et al., 2002). In GluR6, these amino acids correspond to residues E396 and E397. To determine whether similar residues in kainate and NMDA receptors are important for proton inhibition, we examined the effect of mutation of each of these residues as well as three nearby unconserved acidic residues (D388, D390, and 
E400) on proton inhibition of GluR6(Q) receptors (Fig. $4 A$ ). In all cases, aspartate was mutated to asparagine and glutamate to glutamine. Proton inhibition curves were constructed as described previously for each of the mutant receptors. Mutation of the three unconserved residues (D388N, D390N, and E400Q) had no effect on proton inhibition in GluR6. In contrast, mutation of the two conserved residues caused a significant decrease in proton sensitivity of GluR6(Q) (Fig. 4B$D)$. Of the two mutations, E396Q caused a greater decrease in the $\mathrm{IC}_{50}$ for proton inhibition (5.6-fold) than did E397Q (2.8fold). Despite their reduced proton inhibition, mutant GluR6 receptors showed no evidence for potentiation, suggesting that proton potentiation of GluR6/KA1 receptors was unique to the KA1 subunit and not a property of the GluR6 subunit that was masked by the stronger proton inhibition.

Expression of the mutant GluR6Q(E396Q) subunit with the KA2 subunit allowed examination of the effect of this mutation on the heteromeric GluR6(Q)/ KA2 receptor. The mutant GluR6Q(E396Q)/KA2 receptor was inhibited by protons in a biphasic manner, with $\mathrm{IC}_{50}$ values at $\mathrm{pH} 9.0 \pm 0.4$ and $5.4 \pm 0.1$ (Fig. $4 E$ ). The $\mathrm{IC}_{50}$ for the first component of inhibition was similar to that of the wildtype receptor, whereas that for the second component of inhibition was significantly reduced $\left({ }^{*} p<0.05\right)$. Although the $\mathrm{IC}_{50}$ value for the first component of inhibition was unchanged, this component was much more prominent in the proton inhibition curve of the mutant receptor. Thus, these receptors were significantly more inhibited at $\mathrm{pH} 6.8-7.5$ than were wild-type receptors.

\section{Polyamines potentiate GluR6(R) and inhibit GluR6(Q) current}

Small endogenous polyamines, such as spermine, potentiate current through recombinant NMDA receptors. Traynelis et al. (1995) reported that spermine potentiates NMDA responses primarily by relieving tonic proton block of these receptors present at physiological $\mathrm{pH}$ levels. A minor role may also be played by the small polyamine-induced changes in receptor desensitization that have been reported previously (Lerma, 1992; Rumbaugh et al., 2000). If the mechanism of proton inhibition of NMDA and kainate receptors is similar, then polyamines may potentiate GluR6 kainate receptors in a comparable manner. Therefore, to further compare proton inhibition of kainate and NMDA receptors, we tested the effect of polyamines on kainate current through GluR6 receptors.

The effect of polyamines on the GluR6 receptor-mediated current was dependent on the editing state of the Q/R site on the receptor (Fig. 5A). Spermine (1 mM) markedly facilitated the steady-state current at edited GluR6(R) receptors at $\mathrm{pH}$ 7.5. Po- tentiation by spermine was reversible and concentration dependent, with an $\mathrm{EC}_{50}$ of $282 \mu \mathrm{M}$ [95\% confidence interval (C.I.), 191-416 $\mu \mathrm{M} ; n=7]$. This potentiation was mimicked by the polyamine spermidine ( $1 \mathrm{~mm} ; 151 \pm 2.5 \%$ of control; $n=3$ ) but not by the polyamine arthropod toxin PhTx-433 (1 $\mu \mathrm{M} ; 92 \pm$ $6.0 \% ; n=4)$. These findings suggest similarity in the action of spermine on NMDA and kainate receptors.

In contrast to GluR6( $\mathrm{R}$ ) receptors, the unedited $(\mathrm{Q})$ form of the receptor was strongly inhibited by extracellular polyamines at pH 7.5 (Bähring et al., 1997). Spermine (1 mM) and spermidine (1 $\mathrm{mM}$ ) reversibly inhibited kainate currents through GluR6(Q) receptors to $14 \pm 4 \%(n=13)$ and $72 \pm 3 \%(n=5)$ of control, respectively. Inhibition by spermine was reversible and concentration dependent ( $\mathrm{IC}_{50}$ of $66 \mu \mathrm{M}$; 95\% C.I., 25-171 $\mu \mathrm{M} ; n=7$ ) (Fig. 5A). In contrast to its lack of effect on GluR6(R) receptors, PhTx-433 reduced domoate currents at GluR6(Q) receptors to $13 \pm 3 \%$ of control $(n=5)$. The time course for block and recovery of GluR6(Q) receptors by polyamines and polyamine toxins was similar to that reported for GluR2-lacking AMPA receptors (Washburn and Dingledine, 1996). 

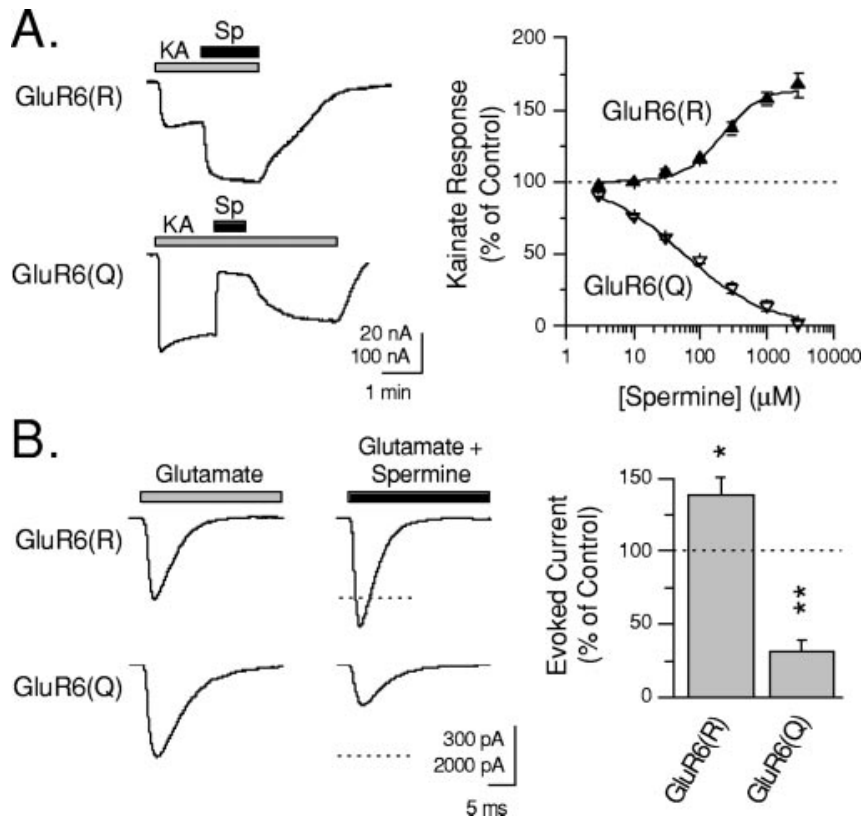

Figure 5. Spermine potentiates GluR6(R) and inhibits GluR6(Q) kainate receptors. A, Sample currents at $\mathrm{pH} 7.5$ from oocytes show potentiation by $1 \mathrm{~mm}$ spermine at $\mathrm{GluR6}(\mathrm{R})$ receptors and inhibition by the same concentration of spermine at $\mathrm{GluR6}(\mathrm{Q})$ receptors. The graph on the right shows the dose-response curve for spermine potentiation at $\mathrm{GluR6}(\mathrm{R})$ receptors and spermine inhibition at $\mathrm{GluR6}(\mathrm{Q})$ receptors. The amplitude of the control current in the absence of spermine is indicated (dotted line). Currents were evoked by $30 \mu \mathrm{m}$ kainate. B, At pH 7.3, currents evoked by rapid application of $3 \mathrm{~mm}$ glutamate to HEK 293 cells expressing GluR6(R) receptors were potentiated by $1 \mathrm{~mm}$ spermine, whereas currents at GluR6(Q) receptors were inhibited. The graph on the right shows that, relative to control (dotted line), spermine produced a significant potentiation of GluR6(R) current $\left(n=6\right.$; $\left.{ }^{*} p<0.05\right)$ and a significant inhibition of GluR6(Q) current $\left(n=5 ;{ }^{* *} p<0.01\right)$ at $\mathrm{pH} 7.3$.

Polyamines had similar effects on GluR6 receptors expressed in mammalian cells. We examined the effect of spermine (1 mM) on currents evoked by rapid application of glutamate to HEK 293 cells transfected with either GluR6(R) or GluR6(Q) receptors. In cells held at $-70 \mathrm{mV}$ at $\mathrm{pH} 7.3$, spermine produced a significant potentiation of the current at GluR6(R) receptors and a significant inhibition of current at GluR6(Q) receptors (Fig. 5B). These effects were reversible during washout of spermine.

Polyamines potentiate NMDA receptors primarily by hindering protonation of residues critical for proton inhibition. Similarity in the mechanism underlying polyamine potentiation of NMDA and GluR6(R) kainate receptors would suggest additional structural parallels in the regions of the two receptors responsible for proton inhibition. We therefore examined the mechanism of polyamine potentiation of GluR6(R).

\section{Spermine potentiation is voltage insensitive}

Spermine potentiation of NMDA receptors is voltage insensitive, suggesting that spermine acts at a site outside the transmembrane electric field (Williams, 1994). To determine whether spermine potentiation of kainate receptors shares similar voltage independence, we examined the effect of spermine on glutamate currents over a range of membrane potentials from -100 to $+100 \mathrm{mV}$. Glutamate-evoked GluR6(R) currents in the absence and presence of spermine were examined in HEK 293 cells at pH 6.0, a pH level at which spermine produces a strong potentiation (Fig. $6 A, B)$. GluR6(R) currents outwardly rectified $\left(\mathrm{RR}_{-100 / 60}, 1.3 \pm\right.$ $0.2)$ and reversed at $-3.5 \pm 1.7 \mathrm{mV}(n=6)$. Spermine markedly potentiated responses at all membrane potentials but did not
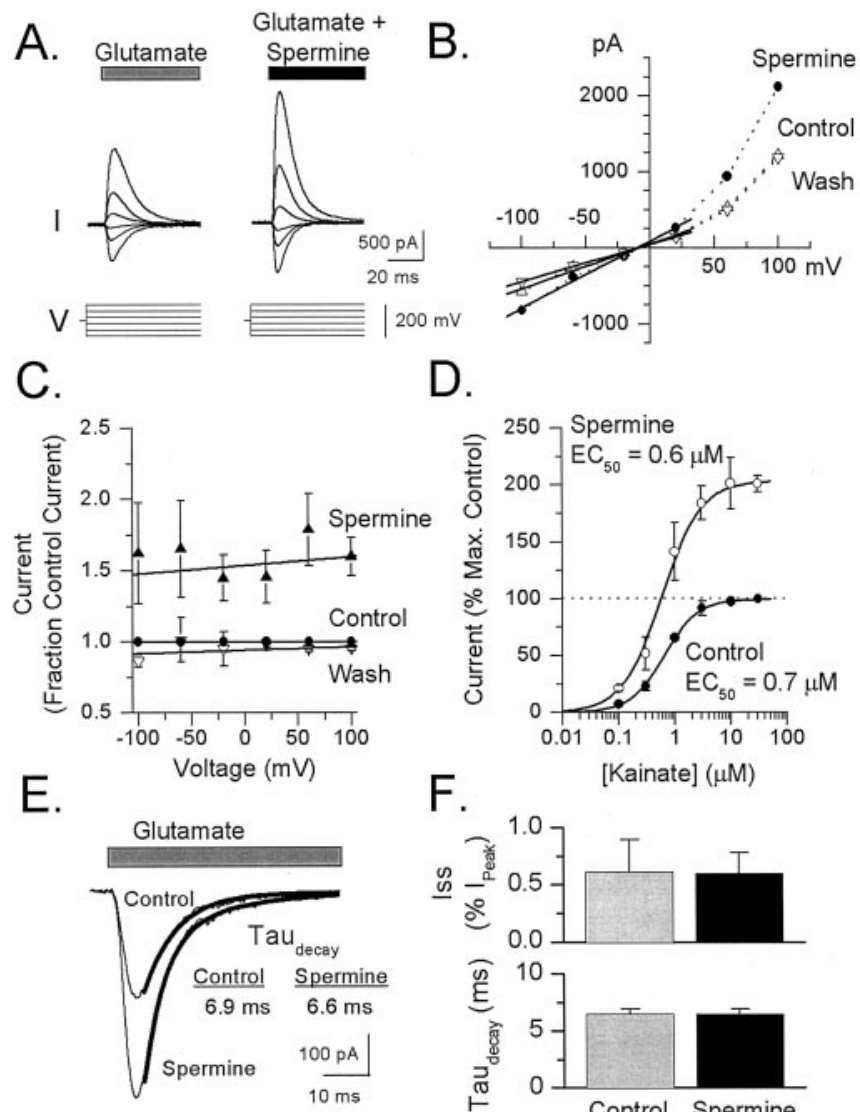

$\mathrm{F}$.

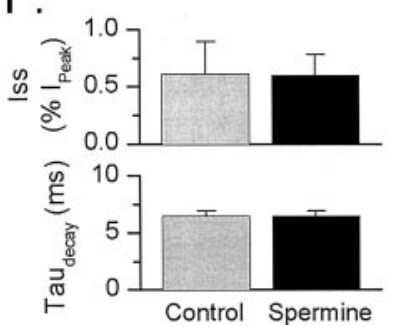

Figure 6. Spermine potentiation of GluR6(R) receptors is voltage independent, does not affect agonist potency, and does not alter receptor desensitization. $A$, Current responses ( $I$ ) recorded at $\mathrm{pH} 6.0$ from GluR6(R) receptors expressed in an HEK 293 cell in response to rapid application of glutamate as the holding potential ( $V$ ) was stepped from -100 to $+100 \mathrm{mV} . B$, The graph shows the $I-V$ curve for GluR6(R) receptors in the absence and presence of spermine in the same cell as in $A$. The slope of the linear portion of the $I-V$ curve increases in spermine by an amount $(65 \%)$ similar to the increase in the peak current $(58 \%)$ at $-60 \mathrm{mV}$. C, The amplitude of the GluR6(R) current in the presence of $1 \mathrm{~mm}$ spermine and in wash was expressed as a fraction of the control current at each holding potential. When the data were fit by linear regression, the slopes of the resulting curves $(0,0.0006$, and $0.0002 \mathrm{mV} /$ fraction control current for control, spermine, and wash, respectively; $n=5$ ) did not differ from zero, indicating voltage independence. $D$, The graph shows the dose-response curve for kainate on GluR6(Q) receptors expressed in oocytes in the absence ( filled circles) and presence (open circles) of $1 \mathrm{~mm}$ spermine at pH 7.5. The dotted line indicates the amplitude of the maximal kainate response in the absence of spermine. $E$, Currents (superimposed in the absence and presence of spermine) at GluR6(R) receptors expressed in HEK 293 cells in response to rapid application of $3 \mathrm{~mm}$ glutamate showed strong potentiation by $1 \mathrm{~mm}$ spermine at $\mathrm{pH}$ 6.0. Monoexponential fits of the current decay revealed little effect of spermine on the onset rate of desensitization. F, Spermine did not affect either the steady-state/peak current ratio (top; $n=6$ ) or the desensitization time constant ( $\tau_{\text {decay }} ;$ bottom; $n=6$ ) of the GluR6(R) current in HEK 293 cells.

alter the reversal potential $(-5.9 \pm 1.1 \mathrm{mV})$ or rectification of the current $\left(\mathrm{RR}_{-100 / 60}, 1.4 \pm 0.2 ; n=6\right)$. For each experiment, the $I-V$ curve in spermine was normalized to that in control, and the resulting curves were combined to yield an averaged plot of the voltage dependence of spermine potentiation (Fig. 6C). The slope of these averaged curves was not significantly different from zero, indicating the lack of any voltage dependence of spermine potentiation.

Spermine does not alter the agonist potency for GluR6(R)

Spermine may potentiate GluR6(R) current by enhancing the agonist potency for the receptor. To test this possibility, we examined the effect of spermine $(1 \mathrm{mM})$ on the $\mathrm{EC}_{50}$ for kainate 
activation of GluR6(R). Concentrationresponse curves to kainate in the absence and presence of spermine revealed a substantial increase in the maximal kainate response in the presence of spermine but no significant difference in the $\mathrm{EC}_{50}$ for kainate (control, $\mathrm{EC}_{50}$ of $0.7 \mu \mathrm{M} ; 95 \%$ C.I., $0.6-0.8 \mu \mathrm{M} ; n=6$; spermine, $\mathrm{EC}_{50}$ of 0.5 $\mu \mathrm{M} ; 95 \%$ C.I., $0.3-0.8 \mu \mathrm{M} ; n=6$ ) (Fig. $6 D)$. Therefore, we conclude that spermine does not potentiate the receptor by enhancing agonist potency.

\section{Spermine does not potentiate kainate responses by altering receptor desensitization}

A spermine-induced decrease in either the rate or extent of receptor desensitization could also contribute to the potentiation. To test this possibility, we examined desensitization of GluR6(R) receptors expressed in HEK 293 cells. Whole-cell currents produced by rapid application of a supramaximal concentration of glutamate ( $3 \mathrm{~mm}$ ) were examined at $\mathrm{pH} 6.0$ in the presence and absence of $1 \mathrm{~mm}$ spermine. In the continual presence of agonist, GluR6(R) currents desensitized rapidly and monoexponentially $\left(\tau_{\text {desens }}=6.5 \pm\right.$ $0.4 \mathrm{msec} ; n=6$ ) (Fig. $6 E$ ). Desensitization was virtually complete, with the steadystate current representing only $\sim 0.6 \%$ of the peak current. Spermine potentiated the peak current (Fig. 5B) but had no effect on the onset rate of desensitization or the steady-state to peak current ratio (Fig. $6 E, F)$. Desensitization of the receptor in the presence of spermine was monoexponential, with $\tau_{\text {desens }}$ $(6.4 \pm 0.5 \mathrm{msec} ; n=6)$ similar to that observed in the absence of spermine. These data indicate that spermine does not potentiate GluR6(R) by altering desensitization of the receptor.

\section{Potentiation by spermine is $\mathrm{pH}$ dependent}

To determine whether spermine potentiates GluR6(R) by relieving proton inhibition, we examined spermine potentiation over a range of $\mathrm{pH}$ values. Potentiation produced by spermine was greatest at acidic $\mathrm{pH}$ levels when proton inhibition of the domoate current was strongest (Fig. 7A). This potentiation became progressively smaller at more basic $\mathrm{pH}$ levels as proton inhibition weakened. Similarly, at GluR6(R) receptors in HEK 293 cells, the current induced by rapid application of glutamate was more strongly potentiated by spermine at $\mathrm{pH} 6.0$ than at $\mathrm{pH} 7.5$ (Fig. $7 B$ ). It is unlikely that ionization of spermine can account for this $\mathrm{pH}$-dependent potentiation because the $\mathrm{p}_{\mathrm{Ka} 4}$ value for spermine $\left(\mathrm{p}_{\mathrm{Ka} 4}=8.3\right)$ falls outside of the range over which spermine has its maximal effects. These data indicate the strong $\mathrm{pH}$ dependence of spermine potentiation.

To further determine whether spermine relieved proton inhibition of GluR6(R), we examined the effect of spermine on the $\mathrm{IC}_{50}$ for proton inhibition of the GluR6(R) receptor expressed in oocytes (Fig. $7 C$ ). Spermine (1 mM) produced a 22 -fold acidic shift in the $\mathrm{IC}_{50}$ for proton inhibition of the receptor (control, $\mathrm{IC}_{50}$ of $\mathrm{pH} 6.9 \pm 0.03, n=5-20$; spermine, $\mathrm{IC}_{50}$ of $\mathrm{pH} 5.6 \pm 0.06$, $n=4-18$ ), shifting the proton sensitivity of the receptor out of the physiological range. These results suggest that, as with NMDA receptors, spermine potentiation of GluR6 $(R)$ is primarily caused by a relief of proton inhibition of the receptor.

At GluR6(Q) spermine consistently inhibited domoate currents at all but the most acidic $\mathrm{pH}$ levels (Fig. 7A). However, at $\mathrm{pH}$ 6.0 , spermine inhibition was reduced, and, in two of six oocytes, spermine potentiation was observed. Consequently, spermine shifted the proton inhibition curve for GluR6(Q) only at the most acidic levels, having no effect at more alkaline $\mathrm{pH}$ values (Fig. $7 D)$. These results are consistent with the interpretation that both the edited (R) and unedited (Q) variants of the GluR6 receptor are potentiated by spermine in a $\mathrm{pH}$-sensitive manner. However, in GluR6(Q) receptors, the potentiation is masked by a coexistent spermine-induced inhibition at all but the most acidic $\mathrm{pH}$ levels. The incomplete editing of GluR6 kainate receptors in the rat brain (Chittajallu et al., 1999) and the opposing effects of polyamines on these editing states suggests that kainate receptors can be expressed with a high degree of specialization to meet the specific needs of their synaptic microenvironment.

\section{Discussion}

The principal finding of the present study is that kainate receptors, like NMDA receptors, are tonically regulated by protons at ambient $\mathrm{pH}$ ( $\mathrm{pH} 7.3$ ), and the extent and direction of this modulation is dependent on the subunit composition of the receptor. For example, we found that homomeric GluR6 receptors and 
heteromeric GluR6(Q)/KA2 receptors are 20-25\% inhibited at resting $\mathrm{pH}$ ( $\mathrm{pH} 7.3$ ), whereas heteromeric GluR6/KA1 receptors are $\sim 30 \%$ facilitated. Tonic regulation of kainate receptors by protons is important because it suggests that both the alkaline and acid shifts in interstitial $\mathrm{pH}$ that accompany neuronal activity could modulate kainate receptor function. In addition, we found that the endogenous polyamine spermine potentiates the GluR6 kainate receptor primarily by relieving this proton inhibition. Given the specialized roles of kainate receptors of different subunit composition (Castillo et al., 1997; Mulle et al., 2000), our results suggest that these endogenous modulatory agents may differentially regulate distinct kainate receptors and thereby exert selective influence over discrete aspects of kainate neurotransmission. These modulatory sites may also provide novel sites for the development of context-dependent and region-selective neuroprotective agents (Mott et al., 1998).

The mechanism underlying the differential effect of protons on distinct kainate receptors is unknown. Swanson et al. (2002) reported that each subunit in a heteromeric kainate receptor contributes an independent agonist-activated conductance to the overall channel response. According to this suggestion, activation or inhibition of individual subunits would shift the conductance state of the channel in a manner similar to that of AMPA receptors (Rosenmund et al., 1998). The biphasic nature of the proton inhibition curve for GluR6/KA2 and the proton potentiation observed for GluR6/KA1 suggest the possibility that protons can act with different affinities on individual subunits in heteromeric kainate receptors. The biphasic proton inhibition curve for GluR6/KA2 may therefore represent selective and independent inhibition of first the higher-affinity KA2 subunit, which reduces the channel conductance, followed by inhibition of the loweraffinity GluR6 subunit, which inhibits the receptor altogether. In support of this idea, we found that replacement of the GluR6 subunit in the heteromeric GluR6/KA2 receptor with a mutated GluR6 subunit [GluR6Q(E396Q)] with lowered proton sensitivity altered the $\mathrm{IC}_{50}$ of the low-affinity, but not the high-affinity, component of the biphasic proton inhibition curve. Although this model represents the most straightforward interpretation of our results, we realize that other more complex scenarios can be imagined.

Although protons may alter kainate receptor gating by inhibiting individual subunits within the receptor, it appears that the proton sensitivity and possibly even the degree of protonation of the individual subunits is influenced by their interaction with other subunits in the receptor. This idea is supported by two findings. First, neither of the two proton $\mathrm{IC}_{50}$ values of the GluR6/KA2 receptor match the $\mathrm{IC}_{50}$ of homomeric GluR6. Second, replacement of wild-type GluR6 with mutant GluR6 in the GluR6/KA2 receptor significantly increases the prominence of the first component of inhibition. Subunit interaction may therefore contribute to the overall proton sensitivity of the receptor and influence the tonic level of proton inhibition at ambient $\mathrm{pH}$. Additional experiments will be necessary to explore these possibilities.

The mechanism by which protons inhibit kainate receptors appears to be similar to that by which protons inhibit NMDA receptors (Traynelis and Cull-Candy, 1991). This conclusion is strengthened by four observations. First, as with NMDA receptors, proton inhibition of kainate receptors is voltage independent, supporting the conclusion that protons do not inhibit kainate receptors by acting at a site within the receptor channel. Second, similar to their effect on NMDA receptors, protons do not alter the desensitization kinetics of kainate receptors. In contrast, protons inhibit AMPA receptors by enhancing desensitiza- tion of the receptor (Ihle and Patneau, 2000; Lei et al., 2001). Third, mutations of conserved residues in GluR6 that reduce proton sensitivity of NMDA receptors also reduce proton sensitivity of kainate receptors. This finding suggests that similar structural elements on both kainate and NMDA receptors mediate proton inhibition. Finally, as with NMDA receptors (Traynelis et al., 1995), spermine potentiated the current through GluR6 receptors by producing an acidic shift in the $\mathrm{p}_{\mathrm{Ka}}$ of the proton sensor. This caused the receptor to become less sensitive to protons. Spermine potentiation of GluR6(R) was voltage independent, did not affect the onset or extent of current desensitization, and did not affect the agonist potency for the receptor. These results suggest that spermine potentiates kainate receptors primarily by relieving proton inhibition of the receptor. They also provide additional confirmation of the similarity in the mechanism of action of protons on kainate and NMDA receptors.

Our results suggest that protons inhibit kainate receptors by acting at a site on the receptor that is outside of the channel pore. Presumably, this site consists of an ionizable residue(s) at which protonation stabilizes the protein in a nonconducting state. It seems likely that this site resides on the extracellular face of the receptor, possibly in the LIVBP-like domain, as has been suggested for the proton sensor on NMDA receptors (Masuko et al., 1999). Indeed, residues that are critical for proton inhibition (E396 and E397) of GluR6 kainate receptors are located between the two lobes of the LIVBP-like domain in GluR6. This is the same location at which the analogous residues (E342 and D343) are found in the NMDA receptor (Masuko et al., 1999). Spermine is thought to relieve proton inhibition of NMDA receptors by binding to a site in the LIVBP-like domain of these receptors near the proton sensor (Masuko et al., 1999). The similarity in the action of spermine on kainate and NMDA receptors is consistent with the possibility that this polyamine could bind to a similar site in the LIVBP-like domain of kainate receptors. Thus, the LIVBPlike domain could act as a common structural element in kainate and NMDA receptors mediating the effects of protons and polyamines. This hypothesis of a modular architecture of ionotropic GluR subunits is consistent with the suggestions of Paoletti and coworkers (Paoletti et al., 2000; Perin-Dureau et al., 2002). However, it is important to note that the GluR6 mutations studied here, although critical for proton inhibition, may not reflect the true location of the proton sensor. Therefore, although it seems unlikely, we cannot exclude the possibility that protons act on a region on the intracellular face of the kainate receptor or a portion of the plasma membrane that is intimately associated with the receptor. Additional studies will be necessary to address these questions.

Kainate receptors of distinct subunit combinations play different functional roles in the brain (Mulle et al., 2000). Potentiation or block of different kainate receptors by protons suggests that proton regulation would be an important factor shaping kainate neurotransmission in the CNS. For example, changes in kainate receptor subunit composition at a synapse during development (Bahn et al., 1994) or after a pathophysiological insult (Mathern et al., 1998) could have marked effects on the proton regulation of kainate neurotransmission at that synapse. Alternately, changes in extracellular $\mathrm{pH}$ that occur under physiological conditions may have implications for kainate receptor function. Proton levels in the brain are not stable and fluctuate rapidly in both the acid and alkaline direction during neuronal activity (Chessler and Kaila, 1992). Because of the selective localization and function of different kainate receptors, $\mathrm{pH}$ changes could have distinct effects on different aspects of kainate neurotransmission. 
Whereas $\mathrm{pH}$ fluctuates during synaptic transmission, the amplitude of this change is much greater during pathophysiological insults, such as spreading depression, seizures, and ischemia, during which interstitial $\mathrm{pH}$ can fall to 6.5 and below for prolonged periods (Somjen, 1984; von Hanwehr et al., 1986). This large decrease in interstitial $\mathrm{pH}$ has been shown to be neuroprotective by inhibiting the activity of NMDA receptors (Kaku et al., 1993). Our results suggest that most kainate receptors would also be inhibited by these large decreases in $\mathrm{pH}$ and that, during certain conditions, such as global ischemia (Sheardown et al., 1990), proton inhibition of kainate receptors may provide some measure of neuroprotection. In particular, our results suggest that protons would be effective at inhibiting steady-state current produced by glutamate spillover onto extrasynaptic kainate receptors. In contrast, GluR6/KA1 receptors are potentiated by protons. Both GluR6 and KA1 subunit are highly expressed in CA3 pyramidal cells (Bahn et al., 1994). Perhaps overactivation of these GluR6/KA1 receptors at acidic $\mathrm{pH}$ levels contributes to the selective vulnerability of this cell population.

\section{References}

Armstrong N, Sun Y, Chen GQ, Gouaux E (1998) Structure of a glutamatereceptor ligand-binding core in complex with kainate. Nature 395:913-917.

Bahn S, Volk B, Wisden W (1994) Kainate receptor gene expression in the developing rat brain. J Neurosci 14:5525-5547.

Bähring R, Bowie D, Benveniste M, Mayer ML (1997) Permeation and block of rat GluR6 glutamate receptor channels by internal and external polyamines. J Physiol (Lond) 502:575-589.

Castillo PE, Malenka RC, Nicoll RA (1997) Kainate receptors mediate a slow postsynaptic current in hippocampal CA3 neurons. Nature 388:182-186.

Chessler M, Kaila K (1992) Modulation of pH by neuronal activity. Trends Neurosci 15:396-402.

Chittajallu R, Braithwaite S, Clarke V, Henley J (1999) Kainate receptors: subunits, synaptic localization and function. Trends Pharmacol Sci $20: 26-35$.

Herb A, Burnashev N, Werner P, Sakmann B, Wisden W, Seeburg PH (1992) The KA-2 subunit of excitatory amino acid receptors shows widespread expression in brain and forms ion channels with distantly related subunits. Neuron 8:775-785.

Ihle EC, Patneau DK (2000) Modulation of $\alpha$-amino-3-hydroxy-5-methyl4-isoxazolepropionic acid receptor desensitization by extracellular protons. Mol Pharmacol 58:1204-1212.

Kaku DA, Giffard RG, Choi DW (1993) Neuroprotective effects of glutamate antagonists and extracellular acidity. Science 260:1516-1518.

Lei S, Orser BA, Thatcher GRL, Reynolds JN, MacDonald JF (2001) Positive allosteric modulators of AMPA receptors reduce proton-induced receptor desensitization in rat hippocampal neurons. J Neurophysiol 85:2030-2038.

Lerma J (1992) Spermine regulates $N$-methyl-D-aspartate receptor desensitization. Neuron 8:343-352.

Lerma J, Paternain AV, Naranjo JR, Mellström B (1993) Functional kainateselective glutamate receptors in cultured hippocampal neurons. Proc Natl Acad Sci USA 90:11688-11692.

Masuko T, Kashiwagi K, Kuno T, Nguyen ND, Pahk AJ, Fukuchi J-I, Igarashi $\mathrm{K}$, Williams K (1999) A regulatory domain (R1-R2) in the amino terminus of the $N$-methyl-D-aspartate receptor: effects of spermine, protons, and ifenprodil, and structural similarity to bacterial leucine/isoleucine/ valine binding protein. Mol Pharmacol 55:957-969.
Mathern GW, Pretorius JK, Kornblum HI, Mendoza D, Lozada A, Leite JP, Chimelli L, Born DE, Fried I, Sakamoto AC, Assirati JA, Peacock WJ, Ojemann GA, Adelson PD (1998) Altered hippocampal kainate-receptor mRNA levels in temporal lobe epilepsy patients. Neurobiol Dis 5:151-176.

Mott DD, Doherty JJ, Zhang S, Washburn MS, Fendley MJ, Lyuboslavsky P, Traynelis SF, Dingledine R (1998) Phenylethanolamines inhibit NMDA receptors by enhancing proton inhibition. Nat Neurosci 1:659-667.

Mott DD, Erreger K, Banke TG, Traynelis SF (2001) Open probability of homomeric murine 5-HT3A serotonin receptors depends on subunit occupancy. J Physiol (Lond) 535:427-443.

Mulle C, Sailer A, Swanson GT, Brana C, O'Gorman S, Bettler B, Heinemann SF (2000) Subunit composition of kainate receptors in hippocampal interneurons. Neuron 28:475-484.

Paoletti P, Perin-Dureau F, Fayyazuddin A, Le Gogg A, Callebaut I, Neyton J (2000) Molecular organization of a zinc binding N-terminal modulatory domain in a NMDA receptor subunit. Neuron 28:911-925.

Perin-Dureau F, Rachline J, Neyton J, Paoletti P (2002) Mapping the binding site of the neuroprotectant ifenprodil on NMDA receptors. J Neurosci 22:5955-5965.

Rosenmund C, Stern-Bach Y, Stevens CF (1998) The tetrameric structure of a glutamate receptor channel. Science 280:1596-1599.

Rumbaugh G, Prybylowski K, Wang JF, Vicini S (2000) Exon 5 and spermine regulate deactivation of NMDA receptor subtypes. J Neurophysiol 83:1300-1306.

Sheardown MJ, Nielsen EO, Hansen AJ, Jacobsen P, Honore T (1990) 2,3Dihydroxy-6-nitro-7-sulfamoyl-benzo(F)quinoxaline: a neuroprotectant for cerebral ischemia. Science 247:571-574.

Somjen GG (1984) Acidification of interstitial fluid in hippocampal formation caused by seizures and by spreading depression. Brain Res 311:186-188.

Sommer B, Kohler M, Sprengel R, Seeburg PH (1991) RNA editing in brain controls a determinant of ion flow in glutamate-gated channels. Cell 67:11-19.

Swanson GT, Green T, Heinemann SF (1998) Kainate receptors exhibit differential sensitivities to (S)-5-iodowillardiine. Mol Pharmacol 53:942-949.

Swanson GT, Green T, Sakai R, Contractor A, Che W, Kamiya H, Heinemann SF (2002) Differential activation of individual subunits in heteromeric kainate receptors. Neuron 34:589-598.

Tang C-M, Dichter M, Morad M (1990) Modulation of the N-methyl-Daspartate channel by extracellular $\mathrm{H}^{+}$. Proc Natl Acad Sci USA 87:6445-6449.

Traynelis SF, Cull-Candy SG (1990) Proton inhibition of N-methyl-Daspartate receptors in cerebellar neurons. Nature 345:347-350.

Traynelis SF, Cull-Candy SG (1991) Pharmacological properties and $\mathrm{H}^{+}$ sensitivity of excitatory amino acid receptor channels in rat cerebellar granule neurons. J Physiol (Lond) 433:727-763.

Traynelis SF, Hartley M, Heinemann SF (1995) Control of proton sensitivity of the NMDA receptor by RNA splicing and polyamines. Science 268:873-876.

von Hanwehr R, Smith ML, Siesjö BK (1986) Extra- and intracellular pH during near-complete forebrain ischemia in the rat. J Neurochem 46:331-339.

Washburn MS, Dingledine R (1996) Block of $\alpha$-amino-3-hydroxy-5methyl-4-isoxazolepropionic acid (AMPA) receptors by polyamines and polyamine toxins. J Pharmacol Exp Ther 278:669-678.

Williams K (1994) Mechanisms influencing stimulatory effects of spermine at recombinant $\mathrm{N}$-methyl-D-aspartate receptors. Mol Pharmacol 46:161-168.

Williams K, Kashiwagi K, Fukuchi J-I, Igarashi K (1995) An acidic amino acid in the $N$-methyl-D-aspartate receptor that is important for spermine stimulation. Mol Pharmacol 48:1087-1098. 